\title{
Perception, Action and the Social Dynamics of the Variable Self
}

\author{
Stephen Reicher \\ School of Psychology \& Neuroscience, University of St. Andrews \\ $\&$ \\ Nick Hopkins \\ Psychology, School of Social Sciences, University of Dundee
}

Address for correspondence: Professor Stephen Reicher, School of Psychology \& Neuroscience, University of St. Andrews, St. Andrews, Fife, KY16 9JP, UK. Email: sdr@standrews.ac.uk 


\section{Revisiting Lewinian Psychology}

Xiao, Coppin \& Bavel have provided a valuable service by reminding us that the subdisciplines of psychology are not to be defined by reference to the specific (and different) phenomena which they address, but by the different levels of analysis at which they address the same phenomena. Social psychology, then, is not limited to looking at behaviour when we are in the company of others but addresses the ways in which social processes shape what we think, feel and do wherever we are and whoever we may be with. The important point about such an approach is that, rather than dividing us into different bunkers addressing different things, it brings us together to ask how the different levels of analysis can be integrated to provide an adequate explanation of the phenomena that interest us all. How can the social, the perceptual and the neural be brought together? What are the processes through which the social world shapes how we see and process and respond to that world? These are big issues, relevant not only to social psychologists and perceptual psychologists but to all in psychology. Thus, to put them on the agenda and provoke debate, is an important accomplishment. So whatever comments we might have about the detail of Xiao et al's argument, and whatever conceptual differences we might have with their approach, we do not want to diminish the significance of this target paper. We are delighted that this conversation is happening and delighted to join it.

Viewed from this perspective, Xiao et al.'s paper can be seen as accomplishing a reinvigoration of Kurt Lewin's classic conceptualisation of social psychology as addressing how the psychological field is socially structured (e.g. Lewin, 1939). Xiao et al.'s second accomplishment is to recognise that the social identity tradition in social psychology - and more specifically, self-categorisation theory (Turner, Hogg, Oakes, Reicher \& Wetherell, 1987; Turner, Oakes, Haslam \& McGarty, 1994) - addresses this question directly. This point 
is little understood, in part due to the way in which this tradition developed. Hence it is worth spending a little time on spelling it out.

\section{The concept of self in the social identity approach}

The concept of social identification originally developed in the context of addressing the specific question of the conditions under which people develop antagonisms towards members of other groups. Tajfel and his colleagues intended to start off with the 'minimal conditions' of group division (mere knowledge of the group membership of two others, one a member of one's own group and one a member of another group), and layer on further conditions until they found evidence of discriminatory behaviours. To Tajfel's surprise, even these minimal conditions led to discrimination (Tajfel, Billig, Bundy \& Flament, 1971) and he was left in a quandry as to why. It was four years before Tajfel, with John Turner, developed an explanation in the form of social identity theory (Turner, 1975; Tajfel \& Turner, 1979). As the name suggests, the core concept here is that of social identity itself.

Social identity is a very simple but a radical concept. First, it introduces the notion of the multiple self. That is, in contrast to the traditional notion that people have a single unified sense of self which marks them out as a unique sovereign individual (or, if they don't, they will suffer for it), it is proposed that the self is a complex system operating at different levels of abstraction. Just as we have a sense of what marks us out as individuals compared to other individuals (personal identity: 'I' vs. 'you'), we also have a sense of what marks us out as members of a particular group compared to other groups (social identity: 'we' vs. 'they'). Moreover, we belong to many groups and so have many different social identities (e.g., as an American, as a physicist, as a woman, as a Muslim etc.). Furthermore, we can potentially define ourselves in terms of yet broader levels of abstraction: as human, as a living creature and so on. The point then is that we have many different selves which are salient at different 
times and which affect our psychological functioning in different ways. Notably, social identity theory proposes that the shift from inter-individual to intergroup behaviour is underpinned by the shift from personal to social identity.

Second, the concept of social identity introduces the notion of the variable self: Who we are, how we see ourselves, how we define our relations to others (indeed whether they are construed as 'other' or as part of the extended 'we' self) is different in different settings. Selfcategorisation theory seeks to explain how this variation in the salience of different identities is determined as a function of context. So too it seeks to explain how the salience of different identities impacts upon psychological functioning. In this latter regard, it has tended to concentrate on two issues. The one is the way that, to the extent that a given social identity is salient, people tend to self-stereotype in terms of the way the relevant group is defined (Haslam \& Turner, 1992, 1995; Turner et al., 1987). To build on the classic 'they saw a game' study with which Xiao and colleagues introduce their argument, it may well be that, on the terraces, watching a game of football, we may bay at the referee if he or she gives a foul to the other team or else fails to give a foul to our own. For the definition of a football fan is to be loyal and passionate. But when we talk about the same game in our lectures then we focus on the evidence not because sanity has suddenly returned, but because, in terms of an academic identity, the values of objectivity and dispassionate evaluation of the facts are now foremost.

The other focus of self-categorisation theory is on how people function together. This, in many ways, is the core aspect of group behaviour. It is not just that we have stereotypes, it is that we have consensual stereotypes. To the extent that people also have consensus in terms of self-stereotyping - they can agree on their norms and values and also on how to act on these in the world - then they are able to act together, to combine their efforts, to accumulate social power and thereby become better able to implement these norms and values. 
That is why groups are so important to the human condition (not simply that they satisfy a need for belonging): they allow us to transform the world we live in materially as well as symbolically. It is a point we often forget, attributing to specific individuals particularly individuals to whom we attribute the magical qualities of leadership - the achievements of groups of followers. But to invoke Berthold Brecht's 'Questions from a worker who reads': "Who built Thebes of the 7 gates? In the books you will read the names of kings. Did the kings haul up the lumps of rock? And Babylon, many times demolished, who raised it up so many times? In what houses of gold glittering Lima did its builders live? Where, the evening that the Great Wall of China was finished, did the masons go?".

The contribution of self-categorisation theory is to show how the formation of consensus and the possibility of co-action depends upon a shared sense of social identity: because group members expect to agree they shape conversations to produce agreement (Haslam, Turner, Oakes, McGarty \& Reynolds, 1998). The ability of leaders to motivate and direct the coordinated actions of followers depends upon their management of that social identity (Haslam, Reicher \& Platow, 2011).

In sum, then, self-categorisation theory is not primarily about specific group phenomena such as stereotyping, category salience, polarization, social influence (even though it addresses them). Nor indeed is it simply about group phenomena in general (indeed many of the principles of self-categorization can be applied at any level of identity, including the individual 'I' vs. 'you' level of personal identity - see for instance McGarty, Mavor \& Skorich, 2015; Reynolds et al., 2010; Skorich \& Mavor, 2013). More fundamentally it develops the position that the way in which the social world impacts the psychological field of the actor is through processes of the variable self (see Reicher, Haslam, Spears \& Reynolds, 2012). 


\section{Exploring the dynamics of the variable self}

Our argument, then, is that the evidence amassed by Xiao and colleagues speaks specifically to the primary ambition of self-categorisation theory. It is certainly reasonable to note that self-categorisation theorists have not exhaustively or rigorously addressed the ways in which self-dynamics moderate the operation of core perceptual processes (in the broad sense of the term to include all sensory modalities). But at the same time, the basic logic of the theory does suggest various ways by which that may occur, and some of these have been addressed conceptually and empirically.

To illustrate this point, it helps to start by appreciating that the notions of the multiple self and of the variable self, apply to (and hence problematise) all self-related terms (which permeate psychology). This point is well appreciated in some cases. Take the term 'selfesteem' for instance. Here we know we must distinguish between individual self-esteem (pertaining to one as an individual) and collective self-esteem (pertaing to that which the same person may derive from membership of a given social group). That is, we know that to ask 'what is someone's self-esteem' makes no sense at all without specifying which of these selves one is referring to (cf. Luhtanen \& Crocker, 1992). This is because one's sense of esteem varies as a function of which self is salient. Yet, there are less obvious and perhaps more significant examples. Let us consider two such terms, self-relevance and self-interest.

Self relevance: Imagine that a Palestinian peasant loses their land in some village you had never heard of on the West Bank. Would you be bothered? Would an article about the event catch your attention and cause you to pause and read? Perhaps, perhaps not. But if you were to define yourself as a Muslim in a world where Muslim's are abused and ignored the answer would most definitely be yes. The event would be happening to 'one of us' and would exemplify 'our' shared plight. It would be highly self-relevant. 
Or again, imagine that a small island at the other end of the world which, at best, you had only vaguely heard of, were occupied by soldiers. Again, would you be bothered? But if your identity as British were made salient and if the islanders were construed as Britons, and if, moreover the invasion seemed to exemplify the act of a bully and invoke British norms of standing up to the bully, then you might be outraged and even support sending a naval task force over 10,000 miles to reverse the situation.

The point is that whether something attracts our attention - whether it is self-relevant or not - depends upon how our self and the event are defined and hence on whether there is a connection between the two. What is more, what grabs our attention, how we construe the meaning of the event and how we respond to it will likewise depend on the selves at play. For instance, when the invaded islands are the Falklands, British observers are likely to notice the national qualities of the islanders and the dictatorial decision of the Argentinian junta, rather than the widespread popular Argentinian feelings about their sovereignty over the islands.

This suggests that there may be processes operating at multiple levels relating to selfrelevance and affecting attentional, encoding and interpretative processes. At the most basic level, it may be that we don't encode the other when they are defined as other to the self. Thus, for instance McClung, Jentzsch and Reicher (2013) used a low level cognitive task (the joint Simon task) in which representation of the other interferes with performance, and found no such interference when the other was construed as outgroup but standard levels of interference when they were construed as ingroup. At a less basic level, we may well notice and encode the plight of the other but decide that it is not worth the effort of intervening. For example, Manchester United football fans who have either their narrow club or their broad football fan identity made salient and who witness someone falling over, offer different levels of help according to whether the person falling wears a Manchester United, a Liverpool (a rival club) or plain red t-shirt (Levine, Prosser, Evans \& Reicher, 2005). When a narrow club 
identity is salient, participants help the ingroup member: the Manchester United shirt wearer. However, when a broader football fan identity is salient, the Manchester United and Liverpool shirt wearers receive equal levels of help (and more than the plain shirt wearer). In similar vein, Wakefield et al., (2011) show that when a given identity (in this case Scottishness) is defined in more versus less inclusive terms, this is consequential for who is listened to and who is helped.

Moving on from whether we take account of events to how we take account of them, a number of pointers emerge from a programme of research we conducted into what is often called the largest collective event on earth - the Magh Mela in Allahabad, Northern India. This is a Hindu festival, at the confluence of the sacred Ganges and Yamuna rivers, which takes place every year but on a 12 year cycle. An ordinary year draws millions of pilgrims. The $6^{\text {th }}$ year draws many more and estimates of the $12^{\text {th }}$ year (or Kumbh Mela) go as high as 100 million. What piqued our interest is that by all the insights of conventional research participation in the Mela should be a highly aversive experience. It is gruelingly cold (especially the pre-dawn bathing in the Ganges which is integral to the ritual); it is intensely crowded; it is incessantly noisy (with endless loudspeakers blaring discordant chants and music night and day) and there are various health risks associated with crowding and the potential for infection transmission. And yet, for all this, people describe the event as blissful or even serene (Hopkins et al., 2015). How can this be?

The answer lies in the way that the sensory experiences have relevance (and hence gain meaning) in relation to the social identities of Hindu pilgrims. By overcoming the cold in performing their devotions, these people (often old and frail) establish their authenticity as believers and gain favour for themselves and their descendants in the long cycle of death and rebirth (Pandey, Stevenson, Shankar, Hopkins \& Reicher, 2014). The size and density of the crowd affirms the importance of the group and the strength of their Hindu beliefs in society 
(Hopkins et al., 2015; Khan et al., 2016). The noise of the crowd, at least when it derives from religious songs, chants and dramas, is experienced as a further affirmation of shared religious devotion and hence as non-intrusive (Shankar, Stephenson, Pandey, Tewari, Hopkins \& Reicher, 2013). Indeed we even have evidence that noises attributed to the Mela, and hence seen as identity relevant, are encoded more richly and remembered better than identical noises attributed to non-identity relevant sources (Srinivasan, et al., 2013; Srinivasan, Tewari, Makwana, \& Hopkins, 2015). Finally, as concerns the issue of proximity and the experience of disgust, we have evidence from elsewhere that bodily excreta (sweat in this case) are experienced as less disgusting when they emanate from an ingroup source (Reicher, Templeton, Neville, Ferrari \& Drury, 2016)

All in all, and across a series of modalities, we see that the identity relevance of stimuli - that is, precisely what they mean in relation to the self and whether they affirm or undermine the self, is critical to the way that they are encoded, evaluated and approached (or else avoided). Indeed, we even have evidence from very different settings (the Kosovan war) that the most extreme events (being injured in war, or losing a loved one) can acquire a positive dimension if the way this happens affirms one's identity as a true child of the nation (Kellezi, Reicher \& Cassidy, 2009).

None of this should come as a surprise. We already know that self-relevance impacts neural activation (Schmitz, Kawahara-Baccus \& Johnson, 2004). We know that selfrelevance affects a variety of cognitive processes from visual search (Chiao, Heck, Nakayama \& Ambady, 2006) to memory (Cunningham, Turk, Macdonald \& Macrae, 2008) to appraisal (Scmitz \& Johnson, 2007). Once one factors in the fact that the self is variable, tied to our different group memberships which become salient as a function of the nature of social context, then we begin to have a powerful means of understanding how social context can come to structure the ways by which we come to understand the reality that confronts us. 
Self interest: All these points gain even more significance when we come to the matter of self-interest. In many ways this is one of the most foundational concepts in the social sciences. After all, rational actor theories start from the premise that human beings act to maximise their self-interest. But on the whole it is presupposed, first, that the self is an individual self thus a good is only of any value if it accrues to me personally - and second that value is to be defined in material terms which, in turn, can be reduced to monetary value (Hopkins \& Kahani-Hopkins, 2004). So rationality then is to be determined by people maximising their individual monetary gains. If they do anything else they are irrational, biased, emotional and the like. Indeed such a view gives a general picture of human beings as incapable of sound judgment (and therefore probably needing their betters to make judgments for them).

However, once one recognises the variability of the self, such that (a) when a good counts as a good to the self, and (b) what counts as a good are both open to question, much of that which is intractable to explanation in terms of rational choice theory (and hence gets defined as irrational) immediately becomes intelligible. Take for instance the issue of altruism. Is it a matter of some hidden benefit to the self (for instance a gain in reputation which one will be able to trade for goods)? Is it a matter of abnegation of the self (such that we no longer think about what is in our interests)? A third possibility, introduced by the concept of social identity, is that it is an extension of the self. Thus, if one defines oneself in terms of a group membership then the good of the group becomes the grounds of self-interest. When, during the Romanian revolution of 1989, protestors in the town of Timisoara opened their shirts to the notorious Securitate troops and declared 'Shoot - there is no point in being alive if Romania is not free', were they being irrational or were they asserting that their individual survival counted for nothing if it impeded the good of the group in terms of which they were defined? 
More generally, an emergent body of identity economists recognise that all economic decisions depend upon the content of our identities and hence what we value (Akerlof \& Kranton, 2011). That is, identities define the terms on the basis of which we calculate which of the options before us best meet our interests. From this perspective it becomes self-evident that we may - depending on whether we define ourselves as a man, a worker, a father, a Jew, a liberal - differentially value material wealth, social status, physical domination, kindness, generosity, the happiness of others.

Given space limitations a handful of illustrations must suffice. Levine and Reicher (1996) report a study involving female physical education (PE) students who were presented with various illness and injury scenarios involving either facial disfigurement (e.g. scarring) or else physical frailty (e.g. brittle bones). When gender identity was made salient and appearance was a key value then the disfigurement scenarios which compromise that identity were seen as more serious. When PE identity was made salient and physical prowess was a key value then the physical frailty scenarios which compromise that identity were seen as more serious. In a similar fashion, it might be that in the context of pilgrimage, the social identity-related concerns of pilgrims are such as to lessen the value placed on health and well-being (Hopkins \& Reicher, 2016 a b). To the outsider this might appear irrational. However, if one takes proper account of the situationally-relevant values and identity concerns, meaningful health interventions can be designed. In another set of studies, Sonnenberg (2004) showed that changing the definition of identity - this time, of the same identity - can even affect the extent to which we value money (a foundational problem for those seeking to establish money as a universal measure of psychological as well as economic value). Thus, when psychology students were asked to compare themselves to divinity students (against whom they see themselves as more materialistic) they valued money more, yet when the comparison was with economics students (next to whom they see themselves as 
less materialistic) they valued money less. More recently, Sonnenberg has begun to explore the real world implications of such differences. Thus, the recent emphasis on students as consumers, with its focus on education as an economic transaction (students pay fees to get higher earning potential in return) has led to students becoming less interested in educational priorities such as actual learning (Sonnenberg, in press).

In all these cases, the judgments and decisions made by actors may depart from what observers consider to make sense. But this is because there is a difference of perspective and identity between the two, and hence in definitions of what constitutes a good to the self. It does not result from differences in the good sense between the observed and the observer. One highly topical example underscores this key point. Katherine Cramer (2016) provides a detailed ethnographic study of rural consciousness in the state of Wisconsin and how it relates to the rise of Scott Walker (which may also now apply to the rise of Donald Trump). One of the questions she asks is why small town dwellers are so antagonistic to higher taxes and to state employees when they would be precisely the people to benefit from a big redistributive state. Just like the white working class vote for Republicans, isn't this a perfect example of not acting in ones interests, "of ignorance or, perhaps, a lack of sophistication" (p. 144)?. In her own voice, Cramer continues: "But there is another way to read these (views). These understandings, whether or not one agrees with them, have roots and reasons behind them" (ibid.).

Cramer then shows how her respondents view and make sense of government spending through the lens of a rural/urban divide, and how, from the perspective of a rural identity, their positions do articulate with their perceived interests. Thus, people believed that Government is run by urbanites who neither understand nor care about rural areas. While they may want more government spending on schools and road-building, they felt (a) so hard-pressed already that they could not afford higher taxes; (b) that government imposed 
regulations did not respect the rural way of life; and (c) money would be spent on urban concerns with little going to the countryside. All in all "why support education spending when you believe that the money collected will not be used to benefit your own district... noone considers the possibility that any of these policies - school aid policy, recreational land designations - were created with rural interests in mind. Instead the lens is of unfairness to rural places and rural people" (p. 164).

To translate all this into the terms we have just been discussing, Cramer's interviewees consider that increased government spending would not accrue to them as rural folk and would not take a form which corresponded to what they value as rural folk. Such spending would not be in their rural self-interest and so they are not being irrational in rejecting it.

\section{Against irrationalism}

The reason we repeatedly address the issue of rationality in this way is that we see it as of both analytic and of normative importance. It is also central to the meta-theory of selfcategorization research. Hence, in their repeated reference to bias (as if group level processes distort our understanding of social reality) this is one place where we feel that Xiao et al. depart both from the social identity tradition and from our own approach.

For Turner and his colleagues, the way we categorise the world reflects the situated structure of social reality (Oakes, Haslam \& Turner, 1994; Oakes, Turner \& Haslam, 1991). That is, group level perception is a fair and veridical representation of reality given the positioning of the subject. People see people in group terms not as a means of simplifying (and thereby distorting) an overly complex array of information but because, sometimes, people are organised in group terms in the real world. The cover of Stereotyping and Social Reality (the Oakes et al., 1994 book) has a picture of police charging protestors in a riot. The 
point is that it would not make sense for these protestors to process how the individual officers differ from each other. What matters in this situation is what these others have in common and how they act in common in relation to the protestors.

Oakes et al. (1994) argue that there is a highly normative dimension to the notion of group perception as intellectually inferior. It translates an ideological preference for the individual over the collective (because collectives provide the powerless with the power to challenge the status quo) into a cognitive hierarchy. It sends out the message 'stay separate, groups are bad for you' (see also Brown, 1988). It is a means of warning against combining in order to challenge the status quo.

We wish to take the argument a step further. There is a tendency to describe human behaviour in general in terms of ignoring, distorting or misusing the information available to us. It is not just in groups that heuristics, biases and emotions prevail. And, as we suggested above, it is easy to discern elitist normative implications: if people cannot process information accurately, they need others to process it for them. This is an attitude we have repeatedly encountered working with government - who, for instance, are reluctant to communicate with the population in the case of emergencies for fear that people will simply panic (even though there is a body of literature to show that it is the self-organisation of ordinary people rather than the intervention of state services that is most effective in such emergencies - see Drury, Cocking \& Reicher, 2009; Drury, Novelli \& Stott, 2013).

Our approach is that humans are meaning-making creatures. We don't reduce information. We evaluate information in order to create sense out of events - this includes what is happening, what it means for us and hence whether/how we should respond to it. Our psychological apparatus is therefore fundamentally creative rather than destructive, and a sense of self is a fundamental aspect of this creative sense-making apparatus. As Cramer 
shows so eloquently, collective identities are particularly effective in enabling our understanding of a complex and opaque social world and of translating mere data into a functional world view.

\section{From perception to action}

Up until now our argument has been broadly consonant with that of Xiao et al. - even if we differ on the issue of bias and rationality. We welcome their broad approach, we welcome their broad understanding of the social identity tradition. What we have sought to do is to show how their arguments sit with that tradition, but also how a self-categorisation approach provides the conceptual framework for understanding the various levels and the various ways in which groups and social identities shape perception and action. To finish, though, we wish to sound a note of caution. That is, while it is certainly critical to examine the articulation of social identity processes with processes of perception, we should not reduce the consequences and antecedents of social identification to matters of perception. Nor indeed should we center social identity on perception. Rather we see social identity processes as being tied to action - more specifically to the organisation of social practice - and we see perception (and also emotion) as an element in that relationship. There are three principal reasons for cautioning against a reductively perceptual account.

First, there is a danger of assuming that group membership is entirely a matter of choice and to ignore the reality of constraint. Being a group member is not just a matter of how I see myself but also a matter of how others see me and who they allow me to be. We may well self-define as a member of a particular social group, say Scots, and see ourselves as fulfilling important criteria of Scottishness (living in Scotland, being committed to the country). But being born in England and with our obvious English accents, will others accept us as such, include us as such, accord us the rights and privileges associated with membership 
(see Hopkins, Reicher \& van Rijswijk, 2015). That cannot be assumed. More consequentially, some of our ancestors, Jews living in Poland, may well have seen themselves as Polish. But were they allowed to be so? Edward Reicher tells a story of when, during the Warsaw Uprising of 1944, he came out of hiding and onto the barricades with a young man. This young man, feeling free at last, cried out to a soldier that Jews and Catholics could at last fight together as Poles. The soldier disagreed. He turned and shot the young man (E. Reicher, 2013).

But it is not just that we can't always be who we see ourselves as being. Very often people are forced to be members of groups they don't necessarily see themselves as being. Do people originally choose to be black, say? Or is it rather that others force them and treat them as such to the extent that they ultimately have little option but to accept the category - even if only as a means of contesting a world structured on racial lines (Carmichael \& Hamilton, 1967). In other words, in a world where others might attack you or exclude you or mistreat you for being black, can you afford not to see yourself (and the other) in racial terms?

Macek (2009) provides a masterly analysis of how such processes operated in Sarajevo under seige during the Bosnian conflict. Perhaps surprisingly, she shows how, initially, the forces defending the city were entirely ethnically integrated. But after Serbs had killed Muslims elsewhere in the country, Muslim defenders began to view those they identified as Serb as potentially untrustworthy. This led those so identified to feel threatened and some defected across the front lines to join the Serbian attackers. This, in turn, solidified the sense of Serbs as untrustworthy. And so, through these intergroup dynamics of misrecognition and mistreatment, categories that everyone rejected at first in time became inescapable. 
The second reason for moving beyond a perceptual account is that it is very static and one- sided. If categories simply reflect the world as it is, how come collectivities are the main basis of social change? Yet, Tajfel and Turner (1979) actually present their analysis of social identity and group processes primary as a model of change. It is quite clear that, even if categories relate to social reality, they are not rigidly tied to the world as it is. This is quite obvious if we think of what are probably the most prevalent set of categories in the contemporary world: national categories. On the one hand we think in terms of nationhood because everyday reality is organised along national terms in even the most banal of ways. When we think of 'the economy doing well/badly' or 'the weather being good/bad' we are generally thinking of the national economy and the national weather. We don't need hot displays of passion for the nation to be structured into our ways of thinking (see Billig, 1995). But at the same time, nationalists use social categories in order to create nation states and national realities where they do not previously exist. Here the category is about creating reality rather than reflecting reality. It is about creating a constituency of people acting together and hence (as we have previously argued) having the power to bring new forms of social organisation into being (Reicher \& Hopkins, 2001). Another way of putting this is to say that social identity processes are oriented to the future not just the present. And, given that the future is not determined, there is space for categories to be contested and argued over. Indeed they are bound to be argued over insofar as they are the basis for creating and influencing new constituencies and hence for wielding social power (Reicher \& Hopkins, 2001). Social identification, then, is not just about perception of what is, it is about mobilisation of people to create what might be.

The third and final reason for not reducing social identities to perception is that this simply isn't the way people gain their understandings. It seems to imply that we are passive beings in a silent world who gaze upon the scenes before us and, individually and 
deliberatively, read off who we are. But on all the issues that concern us and which are at the core of social psychological studies - what we think of others such as migrants or Mexicans or the European Union; our attitudes towards issues such as the economy and climate change; whether we should help the poor or afflicted or displaced - the reality is that every time we turn on the radio or the television or access a website or read a newspaper, we are assailed by multiple voices positioning us in different ways and telling us what to think. Inevitably, this returns us to the issue of group members' 'interest' discussed earlier. Argument over the relevance and meaning of any social category, and who and what best represents that category, implies argument over group members' interests and futures (Hopkins \& KahaniHopkins, 2004).

In a complex social world, where the evidence is uncertain and we often lack the expertise to evaluate arguments, we have to make decisions about which voice to attend to and who to trust. And that depends upon the way we position ourselves in relation to the various speakers. Understanding is therefore bound up with issues of leadership (Haslam et al., 2011) and there is a double sense in which leaders are involved in mobilising identity. First, they appeal to us on the basis of shared identities ('I am the voice of ordinary people like you'); second, they seek to sway us by relating events to these identities (oppose this policy because it is bad for ordinary people). If we limit ourselves to perception, we sideline ourselves from understanding the contemporary events that are making our world (see Reicher \& Haslam, in press).

\section{Conclusion}

Let us finish as we started. We welcome the target paper and hope it will generate widespread debate that exerts a centripetal force on psychology in an increasingly centrifugal world. That is, how do groups and social identities structure our perception (and our psychological field 
more generally), thereby shaping our actions. We have sought to contribute to this debate by drawing out the logic of self-categorisation theory and showing how it provides a framework for answering these questions. At the same time we have raised two concerns. The first relates to the dangers of linking groups and irrationalism (or, more generally, taking an irrationalist perspective on human understanding). The other relates to the problem of taking perception as the whole story rather than just a part of it. We offer these thoughts in the hope of generating yet further debate. To paraphrase Humphrey Bogart's final words in Casablanca, we hope that this is the beginning of a beautiful discussion. 


\section{References}

Akerlof, G.A., \& Kranton, R.E. (2011). Identity Economics: How our identities shape our work, wages and well-being. Princeton, NJ: Princeton University Press.

Billig, M. (1995). Banal Nationalism. London: Sage.

Brown, R. (1988) Group Processes. Oxford: Blackwell.

Carmichael, S., \& Hamilton, C.V. (1967). Black Power. New York: Vintage Books.

Chiao, J. Y., Heck, H. E., Nakayama, K., \& Ambady, N. (2006). Priming race in biracial observers affects visual search for Black and White faces. Psychological Science, 17, 387-392.

Cramer, K.J. (2016). The Politics of Resentment: Rural Consciousness in Wisconsin and The Rise of Scott Walker. Chicago: The University of Chicago Press.

Cunningham, S. J., Turk, D. J., Macdonald, L. M., \& Macrae, C. N. (2008). Yours or mine? Ownership and memory. Consciousness and cognition, 17, 312-318.

Drury, J., Cocking, C., \& Reicher, S.D. (2009). The nature of collective resilience: Survivor reactions to the 2005 London bombings. International Journal of Mass Emergencies and Disasters, 27, 66-95.

Drury, J., Novelli, D., \& Stott, C. (2013). Psychological disaster myths in the perception and management of mass emergencies. Journal of Applied Social Psychology, 43, 22592270.

Haslam, S.A., Reicher. S.D. \& Platow, M. (2011). The New Psychology of Leadership. London: Psychology Press.

Haslam, S. A., \& Turner, J. C. (1992). Context-dependent variation in social stereotyping 2: The relationship between frame of reference, self-categorization and accentuation. European Journal of Social Psychology, 22, 251-277. 
Haslam, S. A., \& Turner, J. C. (1995). Context-dependent variation in social stereotyping 3: Extremism as a self-categorical basis for polarized judgement. European Journal of Social Psychology, 25, 341-371.

Haslam, S. A., Turner, J. C., Oakes, P. J., McGarty, C., \& Reynolds, K. J. (1998). The group as a basis for emergent stereotype consensus. European Review of Social Psychology, 8, 203-239.

Hopkins, N., \& Kahani-Hopkins, V. (2004). Identity construction and political activity: Beyond rational actor theory. British Journal of Social Psychology, 43, 339-356.

Hopkins, N., \& Reicher, S. (2016a). The psychology of health and well-being in mass gatherings: A review and a research agenda. Journal of Epidemiology and Global Health, 6, 49-57.

Hopkins, N., \& Reicher, S. (2016b). Adding a Psychological Dimension to Mass Gatherings Medicine. International Journal of Infectious Diseases. doi:10.1016/j.ijid.2015.12.017

Hopkins, N., Reicher, S.D., \& van Rijswijk, W. (2015).Everyday citizenship: Identity claims and their reception. Journal of Social and Political Psychology, 3, 84-106.

Hopkins, N., Stevenson, C., Shankar, S., Pandey, K., Khan, S. \& Tewari, S. (2015). Being together at the Magh Mela: The social psychology of crowds and collectivity. In Gale, T. Maddrell, A., \& Terry, A. (eds.). Sacred Mobilities (pp. 19-40). Farnham, UK: Ashgate.

Kellezi, B., Reicher, S., \& Cassidy, C. (2009). Surviving the Kosovo Conflict: A Study of Social Identity, Appraisal of Extreme Events, and Mental Well-Being. Applied Psychology, 58, 59-83. 
Khan, S., Hopkins, N., Reicher, S., Tewari, S., Srinivasan, N. \& Stevenson, C. (2016). How Collective Participation Impacts Social Identity: A Longitudinal Study From India. Political Psychology. DOI: 10.1111/pops.12260.

Levine, R. M., \& Reicher, S. D. (1996). Making sense of symptoms: Self-categorization and the meaning of illness and injury. British Journal of Social Psychology, 35, 245-256.

Levine, M., Prosser, A., Evans, D., \& Reicher, S.D. (2005). Identity and emergency intervention: How social group membership and inclusiveness of group boundaries shape helping behavior. Personality and Social Psychology Bulletin, 31, 443-453.

Lewin, K. (1939) Field theory and experiment in social psychology: Concepts and methods. American Journal of Sociology, 44, 868-896.

Luhtanen, R., \& Crocker, J. (1992). A collective self-esteem scale: Self-evaluation of one's social identity. Personality and Social Psychology Bulletin, 18, 302-318.

Macek, I. (2009) Sarajevo under Siege: Ethnography in Wartime. Phildelphia, Pa: University of Pennsylvania Press

McLung, J., Jentzsch, I. \& Reicher, S.D. (2013) Group membership affects spontaneous mental representation: Failure to represent the out-group in a joint action task. PLoS ONE, 8 (11): e79178.

McGarty, C., Mavor, K. I., \& Skorich, D. P. (2015). Social categorization. In J. D. Wright (Ed.), International Encyclopedia of the Social and Behavioral sciences $\left(2^{\text {nd }}\right.$ Ed, vol 22, pp. 186-191). Oxford, UK: Elsevier.

Oakes, P. J., Haslam, S. A., \& Turner, J. C. (1994). Stereotyping and Social Reality. Oxford, UK: Blackwell.

Oakes, P. J., Turner, J. C., \& Haslam, S. A. (1991). Perceiving people as group members: The role of fit in the salience of social categorizations. British Journal of Social Psychology, 30, 125-144. 
Pandey, K., Stevenson, C., Shankar, S., Hopkins, N., \& Reicher, S. D. (2014). Cold comfort at the Magh Mela: Social identity processes and physical hardship. British Journal of Social Psychology, 53, 675-690.

Reicher, E. (2013) Country of Ash: A Jewish Doctor in Poland, 1939-1945. New York: Bellevue Literary Press.

Reicher, S.D., \& Haslam, S.A. (in press) Donald Trump and the politics of hope: a social identity analysis of the leader's appeal. In M. Fitzduff (Ed.) Why Irrational Politics Appeals. Santa Barbara: Praeger.

Reicher, S. D., Haslam, S. A., Spears, R., \& Reynolds, K. J. (2012). A social mind: The context of John Turner's work and its influence. European Review of Social Psychology, 23, 344-385.

Reicher, S.D., \& Hopkins, N.P. (2001) Self and Nation. London: Sage

Reicher, S. D., Templeton, A., Neville, F., Ferrari, L., \& Drury, J. (2016). Core disgust is attenuated by ingroup relations. Proceedings of the National Academy of Sciences, 201517027.

Reynolds, K. J., Turner, J. C., Branscombe, N. R., Mavor, K. I., Bizumic, B., \& Subacic, E. (2010). Interactionism in personality and social psychology: An integrated approach to understanding the mind and behaviour. European Journal of Personality, 24, 458482.

Schmitz, T. W., \& Johnson, S. C. (2007). Relevance to self: a brief review and framework of neural systems underlying appraisal. Neuroscience \& Biobehavioral Reviews, 31, $585-596$.

Schmitz, T. W., Kawahara-Baccus, T. N., \& Johnson, S. C. (2004). Metacognitive evaluation, self-relevance, and the right prefrontal cortex. Neuroimage, 22, 941-947. 
Shankar, S., Stevenson, C., Pandey, K., Tewari, S., Hopkins, N. \& Reicher, S. D. (2013). A calming cacophony: Social identity can shape the experience of loud noise. Journal of Environmental Psychology, 36, 87-95.

Skorich, D. P. \& Mavor, K. I. (2013). Cognitive load privileges memory-based over datadriven processing, not group-level over person-level processing. British Journal of Social Psychology, 52, 469-488.

Sonnenberg, S.J. (2004). Money \& Self: Towards a social psychology of money and its usage. University of St. Andrews: Unpublished PhD Thesis.

Sonnenberg, S. J. (in press). Student identity and the marketisation of Higher Education, in Mavor, K. I., Platow, M. J. and Bizumic, B (Eds). Self and social identity in educational contexts. London: Routledge.

Srinivasan, N., Tewari, S., Makwana, M., \& Hopkins, N. (2015). Attention mediates the effect of context-relevant social meaning on prospective duration judgments. Timing \& Time Perception, 3, 189-200.

Srinivasan, N., Hopkins, N., Reicher, S. D., Khan, S. S., Singh, T., \& Levine, M. (2013). Social meaning of ambiguous sounds influences retrospective duration judgments. Psychological science, 24, 1060-1062.

Tajfel, H., Billig, M. G., Bundy, R. P., \& Flament, C. (1971). Social categorization and intergroup behavior. European Journal of Social Psychology, 1, 149-178.

Tajfel, H., \& Turner, J. C. (1979). An integrative theory of intergroup conflict. In W. G. Austin \& S. Worchel (Eds.), The Social Psychology of Intergroup Relations (pp. 3347). Monterey, CA: Brooks/Cole.

Turner, J.C. (1975) Social comparison and social identity; some prospects for intergroup behaviour. European Journal of Social Psychology, 5, 5-34. 
Turner, J. C., Hogg, M. A., Oakes, P. J., Reicher, S. D., \& Wetherell, M. S. (1987).

Rediscovering the social group: A self-categorization theory. Cambridge, MA:

Blackwell.

Turner, J. C., Oakes, P. J., Haslam, S. A., \& McGarty, C. (1994). Self and collective:

Cognition and social context. Personality and Social Psychology Bulletin, 20, 454454.

Wakefield, J.R.H., Hopkins, N. Cockburn, C. Shek, K.M.,Muirhead, A., Reicher, S. \& van Rijswijk, W. (2011). Impact of Adopting Ethnic or Civic Conceptions of National Belonging for Others' Treatment. Personality \& Social Psychology Bulletin, 37, 1599-1610. 